\title{
Bacterial microleakage at the implant-abutment interface in Morse taper implants
}

\author{
João Paulo da Silva-Neto ${ }^{1}$, Marina de Freitas Fratari Majadas², Marcel Santana Prudente', \\ Thiago de Almeida Prado Naves Carneiro², Mario Paulo Amante Penatti ${ }^{3}$, Flávio Domingues das Neves $^{2}$
}

\author{
${ }^{1}$ Universidade Federal do Rio Grande do Norte - UFRN, School of Dentistry, Department of Prosthodontics, Natal, RN, Brazil \\ ${ }^{2}$ Universidade Federal de Uberlândia - UFU, School of Dentistry, Department of Occlusion, Fixed Prostheses, and Dental Materials, Uberlândia, MG, Brazil \\ ${ }^{3}$ Universidade Federal de Uberlândia - UFU, Technical School of Health, Uberlândia, MG, Brazil
}

\begin{abstract}
Aim: To evaluate the microleakage at the implant-abutment (I-A) interface of Morse tapered implants inoculated with different volumes of bacterial suspension. Methods: Morse tapered IA sets were selected and divided in two groups depending on the type of abutment: passing screw (PS) and solid (S), and then subdivided into four subgroups ( $n=6)$ according to the suspension volume: PS1: $0.1 \mu \mathrm{L} ;$ PS3: $0.3 \mu \mathrm{L}$; PS5: $0.5 \mu \mathrm{L} ;$ PS7: $0.7 \mu \mathrm{L}$; S1: $0.1 \mu \mathrm{L} ; \mathrm{S3}: 0.3$ $\mu \mathrm{L} ; \mathrm{S} 5: 0.5 \mu \mathrm{L}$ and S7: $0.7 \mu \mathrm{L}$. A control test was performed to verify the presence of external contamination during the inoculation and the implants were incubated for microbiological analysis. The microleakage was evaluated every $24 \mathrm{~h}$ for 7 days by the clarity of solution. After this period, the implants were disassembled for confirmation of bacterial viability. Results: All the specimens with $0.7 \mu \mathrm{L}$ and one sample of $\mathrm{S} 5$ presented turbidity in the control test indicating external contamination, and were excluded from the study. After 7 days of observation, none of the specimens presented positive results for microleakage and the bacterial viability was confirmed in all specimens. The $0.1 \mu \mathrm{L}$ and $0.3 \mu \mathrm{L}$ volumes did not present bacterial microleakage, meaning that these volumes may be inadequate for analysis. Conclusions: None of the sets evaluated showed bacterial microleakage at the I-A interface and the volume of $0.7 \mu \mathrm{L}$ exceeded the internal capacity of the implants.
\end{abstract}

Keywords: dental implants; dental abutments; microbiology.

\section{Introduction}

Failures in implant therapy have been associated with lack of stability or misfit at the implant-abutment (I-A) interface ${ }^{1}$. Two-piece implants have a microgap depending on the interface type or system, but presence of fluid flow at this interface and its relationships are very variable ${ }^{2-18}$. This has been correlated to the presence of bacterial infiltration and inflammatory cells that may lead to

Received for publication: February 20, 2014 Accepted: March 28, 2014

Correspondence to: João Paulo da Silva Neto

Departamento de Prótese - Faculdade de Odontologia Universidade Federal do Rio Grande do Norte Avenida Sen. Salgado Filho 1787

CEP: 59056-000 Lagoa Nova, Natal, RN, Brasil Phone: + 558432153883

E-mail: joaopaulosneto@gmail.com bone loss around this area ${ }^{19}$.

Implant manufacturers try to reduce bacterial infiltration by increasing the accuracy and stability of the jointed pieces by fabricating very high precision mechanical parts ${ }^{7}$. Internal conical joints have greater mechanical stability of the I-A interface and have shown no crest bone $\operatorname{loss}^{20-21}$. This has been explained by the stress distribution of the implant's long axis during function. The greater stability of the soft tissues provided by the tapered abutment design and its reduced diameter relative to the platform and absence of abutment micromobility by the self-locking feature reduces bacterial leakage at the interface or even prevents $\mathrm{it}^{3-7}$. 
In vitro bacterial studies at the I-A interface of Morse taper implants have attempted to assess the actual advantage of mechanical locking of these joints, but variable results were found ${ }^{2-8,18}$. These variations may be related to methodological bias in the tests such as: holding implants with forceps; hand inoculation of the bacterial suspension into the implants; using one single torquemeter for all samples; failure to measure the inner volume of the implant; using a higher amount of bacterial suspension than should be used; type of bacteria and its viability within the study conditions, and the sterile technique used when studying the inward flow from the outer part of the implant ${ }^{15}$.

Different volumes of bacterial suspension for implants inoculation could minimize the variations found in the literature. Therefore, the objective of this study was to assess the microleakage at the I-A interface of Morse tapered implants with different abutments and to verify the influence of different volumes of bacterial suspension.

\section{Material and methods}

Forty-eight Morse taper implants $(3.75$ x $11.5 \mathrm{~mm}$ NEODENT $^{\circledR}$, Curitiba, PR, Brazil) and 24 passing screw abutment (PS) and solid abutments (S) $\left(4.5 \times 6 \times 1.5 \mathrm{~mm} ; 11.5^{\circ}\right.$ - Neodent ${ }^{\circledR}$, Curitiba, PR, Brazil) were selected and assigned to two groups according to the type of abutment (PS and S). The assemblies of both groups were further subdivided into four subgroups according to the amount of bacterial suspension inoculated into the inner part of the implants (n=6). PS1: $0.1 \mu \mathrm{L}$; PS3: $0.3 \mu \mathrm{L}$; PS5: $0.5 \mu \mathrm{L}$; PS7: $0.7 \mu \mathrm{L}$; S1: $0.1 \mu \mathrm{L}$; S3: $0.3 \mu \mathrm{L}$; S5: $0.5 \mu \mathrm{L}$ and S7: $0.7 \mu \mathrm{L}$ (Table 1).

Escherichia coli strain ATCC 35218 was selected for bacterial microleakage evaluation because it is a facultative anaerobic bacterium, able to survive in adverse situations and has a good motility, and has been used in other in vitro tests $2,5,7,13-14$. This bacterium was cultivated in brain heart infusion broth - BHI (Biolife, Milano, Italy) for $24 \mathrm{~h}$ in an incubator at $37{ }^{\circ} \mathrm{C}$ (Biomatic, Porto Alegre, RS, Brazil). All the used instruments were autoclaved at $121{ }^{\circ} \mathrm{C}$ and $15 \mathrm{psi}$ for $15 \mathrm{~min}$. All the procedures and necessary materials were conducted under the clean conditions of a laminar flow hood (Veco, Campinas, SP, Brazil). A standard bacterial suspension dilution of $0.5 \mathrm{McF}$ arland $\left(10^{8}\right.$ colony forming unit $/ \mathrm{mL}-$ $\mathrm{CFU} / \mathrm{mL}$ ) was used for minimizing the environmental adversity inside of the implants. The implants were set on a holder and an automatic pipette $(0.1-20 \mu \mathrm{L}$, Labmate $+\mathrm{HT}$; PZ HTL S.A, Warsaw, Poland) was fixed to the vertical shaft of a prosthetic surveyor (BIOART, São Carlos, SP, Brazil.) ${ }^{14}$. The pipette tip was inserted and loaded with the amount that was required for each experimental group.
After the inner part of the implant had been inoculated, the abutment was opened and carefully installed using sterile pliers. It was then tightened according to the manufacturer's recommendations by a manual torquemeter individually calibrated for each sample.

Control Test. All assemblies were immersed for $30 \mathrm{~s}$ in tubes containing sterile BHI broth until the I-A interface was completely coated. This test determined if there was any external contamination during the abutment installation and screw tightening process. The tubes of the control test were maintained in an incubator at $37{ }^{\circ} \mathrm{C}$ for up to 7 days in order to evaluate every $24 \mathrm{~h}$ the changes in the broth turbidity. A turbid broth indicated bacterial leakage during inoculation and/or abutment installation and that sample was excluded.

For negative control, the abutment was not connected to the implant and was not subjected to bacterial suspension and showed no turbidity. For positive control, the abutment was not connected to a fixture, but was subjected to the same bacterial culture as the groups and presented turbidity.

After the implants immersion in the control tubes, all the I-A samples were kept in microcentrifuge tubes (Eppendorf, Hamburg, Germany) with another sterile BHI broth until reaching the I-A interface coating. The I-A samples were also evaluated every $24 \mathrm{~h}$ by the same method of the control test. After 7 days, if no bacterial growth was observed, the I-A samples were opened in the laminar flow hood and the disassembled components were placed in a new tube with sterile BHI to assess the viability of the bacteria by turbidity. If the bacteria were not viable after this period, the sample would be excluded to prevent a false negative result.

\section{Results}

To validate the colonization and detection techniques, abutments similar to those in PS and S were kept disassembled and either exposed to bacterial culture or maintained sterile. Zero CFUs of E. coli were detected from sampling of abutments that were maintained sterile (negative control) (Figure 1A), whereas $10 \mathrm{McF}$ arland $\left(30 \times 10^{8} \mathrm{CFU} / \mathrm{mL}\right)$ of $E$. coli were detected in samples from abutments exposed to bacterial culture (positive control) (Figure 1B).

After the first $24 \mathrm{~h}$ of follow up one specimen of the control groups S5 and all the PS7 and S7 samples presented turbidity of the solution, which indicates bacterial contamination and they were excluded from the study. During the period of 7-day follow up, none of the other specimens presented positive results for bacterial microleakage (Table 2) (Figure 1C). The viability test using the disassembled components of I-A samples confirmed that E. coli survived inside the implants.

Table 1. Features of the groups tested.

\begin{tabular}{llllllll}
\hline Groups & $\mathrm{n}$ & & \multicolumn{2}{c}{ Volume $(\mu \mathrm{L})$} & & abutment & recommended tightening torque \\
MTps & $\begin{array}{l}6 \text { for } \\
\text { each }\end{array}$ & 0.1 & 0.3 & 0.5 & 0.7 & $\begin{array}{l}\text { Passive } \\
\text { screw }\end{array}$ & $15 \mathrm{Ncm}$ \\
MTs & $\begin{array}{l}\text { volume } \\
\text { volum }\end{array}$ & 0.1 & 0.3 & 0.5 & 0.7 & Solid & $32 \mathrm{Ncm}$ \\
\hline
\end{tabular}




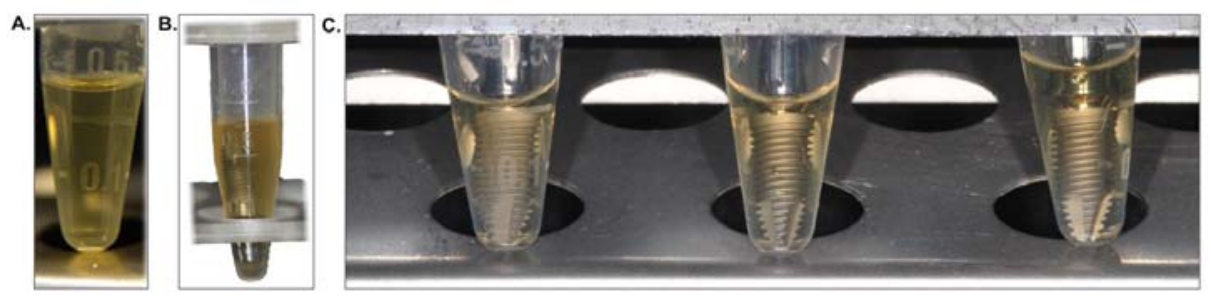

Fig. 1. A. Negative control; B. Positive control; C. Negative results for bacterial microleakage during the 7 days period.

Table 2. Results

\begin{tabular}{llll}
\hline Groups & 1 & 3 & 5 \\
PS & - & - & - \\
S & - & - & - \\
\hline
\end{tabular}

\section{Discussion}

All the specimens inoculated with $0.7 \mu \mathrm{L}$ presented turbidity of the solution in the control test after the first $24 \mathrm{~h}$, which indicated bacterial contamination. This showed that during the installation of the abutments, the volume of inoculation exceeded the internal capacity of the implants. Only one specimen of the S5 group presented positive results in the control test, but it may be due to problems in the experimental step rather than an inability to accommodate the volume in the inner parts of the implants. These results showed that for the studied system, the maximum volume is around $0.5 \mu \mathrm{L}$. Other studies evaluating Morse tapered systems used $0.1 \mu \mathrm{L}$ to $0.5 \mu \mathrm{L}$ of volume inoculation ${ }^{2,4-5,7}$. However, only two studies reported the evaluation of the best inner volume for the studied system and used the same volume for different conical systems $\mathrm{s}^{4-5}$. The other studies did not find any difference among the internal volumes of the systems ${ }^{2,7}$.

The groups inoculated with $0.7 \mu \mathrm{L}$ were excluded due to the positive results of the control test. For the other groups, after the period of 7-day follow up, none of the evaluated specimens showed positive results for bacterial microleakage at the I-A interface. These results corroborate studies under static conditions where Morse tapered implants showed reduced levels of bacterial flow in the I-A interface ${ }^{4,6-7}$, although there was no consensus ${ }^{5-6}$. Alterations in the shape of the abutments may also have harmed the mechanical imbrication of the conical interfaces allowing greater bacterial flow in the interface ${ }^{3,6}$, which was not observed in this study.

The use of reduced volumes of bacterial suspension for inoculation, with high concentrations (superior to $1.5 \times 10^{8}$ $\mathrm{CFU} / \mathrm{mL}$ ) and longer periods of follow up, over 7 days, may create an extremely adverse environment for bacterial survival inside the implants, reducing significantly the possibility of microleakage, because of the bacterial competition. These volumes may also lead to low levels of bacterial suspension in relation to the I-A interface, hindering the microleakage ${ }^{15}$ and showing negative results for microleakage as in previous studies ${ }^{7,16}$. These results reinforce the theory that high concentrations of bacteria and reduced volumes may mask the microleakage ${ }^{14-15}$. Moreover, it may lead to false negative results caused by bacterial death inside the implants. In order to avoid this, beyond the precautions on the concentration of bacterial suspension, bacterial viability was confirmed after the follow up period by disassembling the specimens that presented negative results for microleakage. Precaution involving the concentration of bacterial suspensions is already a reality; ${ }^{4,5,14}$ but confirmation of bacterial viability was made only in two studies ${ }^{5,14}$.

The chosen post-inoculation control test was immersion of the implants up to the I-A interface coating for $30 \mathrm{~s}$. The overflow control by immersion was used in a previous study and showed good results 9 . Currently, in vitro tests for microleakage with corpuscular bacteria showed no flow at the I-A interface, even in hexagonal joints, contradicting what was previously thought $t^{9,14}$. Even though these findings may be different in situations of mechanical load, inner joints are more stable and could be more beneficial, but few studies compared this situation ${ }^{3,13}$.

Moreover, tests using dyes and bacterial toxins of molecular sizes, which are the real cause of marginal bone crest resorption, showed that microleakage occurs even in Morse tapered joints regarded as hermetically stable, and even in absence of load, its flow increases with time ${ }^{8,11}$. Therefore, more studies are required using bacteria, dyes and bacterial toxins under load conditions. These studies will guide the understanding about the flow that occurs at this interface and its relation to the microgap. This may solve clinical problems related to this process, mainly during the first years in function.

The present study verified that despite the fact that tests for bacterial viability showed that the volumes of 0.1 and $0.3 \mu \mathrm{L}$ allowed the survival of bacteria during the period of 7 days, it may be insufficient to evaluate the microleakage at the I-A interface, since it did not occupy the maximum capacity of the inner parts of the implant. The $0.5 \mu \mathrm{L}$ volume showed that it could be used for in vitro tests using Morse tapered implants with different abutments (PS and S), without overflow of the volume after abutment installation. The need of determining and using the closest volume of the inner parts of the implants and controlling the bias related to the methodology should be underlined in order to avoid false positive or negative results.

Within the limitations of this study, it may be concluded that the volume of 0.7 exceeds the inner capacity and should not be used. None of the other evaluated specimens showed bacterial microleakage at the I-A interface. However, the volumes of 0.1 and 0.3 may be insufficient for future tests. 
This suggests that the $0.5 \mu \mathrm{L}$ volume seems to be closer to ideal for the studied groups.

\section{Acknowledgements}

This research was supported by CAPES: Coordination for the improvement of Higher Education Personnel, Brazil. The authors would like to thank Neodent Implante Osteointegrável for the donation of implants and abutments and the Microbiology Laboratory of the Technical School of Health - Federal University of Uberlândia.

\section{References}

1. Goodacre CJ, Bernal G, Rungcharassaeng K, Kan JY. Clinical complications with implants and implant prostheses. J Prosthet Dent. 2003; 90: 121-32.

2. Jansen VK, Conrads G, Richter EJ. Microbial leakage and marginal fit of the implant-abutment interface. Int J Oral Maxillofac Implants. 1997; 12: 52740.

3. Koutouzis T, Wallet S, Calderon N, Lundgren T. Bacterial colonization of the implant-abutment interface using an in vitro dynamic loading model. J Periodontol. 2011; 82: 613-8.

4. Aloise JP, Curcio R, Laporta MZ, Rossi L, da Silva AM, Rapoport A. Microbial leakage through the implant-abutment interface of Morse taper implants in vitro. Clin Oral Implants Res. 2010; 21: 328-35.

5. Deconto MA, Salvoni AD, Wassall T. In vitro microbiological bacterial seal analysis of the implant/abutment connection in morse taper implants: a comparative study between 2 abutments. Implant Dent. 2010; 19: 158-66.

6. Tesmer M, Wallet S, Koutouzis T, Lundgren T. Bacterial colonization of the dental implant fixture-abutment interface: an in vitro study. J Periodontol. 2009; 80: 1991-7.

7. Dibart S, Warbington M, Su MF, Skobe Z. In vitro evaluation of the implantabutment bacterial seal: the locking taper system. Int J Oral Maxillofac Implants. 2005; 20: 732-7.

8. Harder S, Dimaczek B, Acil Y, Terheyden H, Freitag-Wolf S, Kern M. Molecular leakage at implant-abutment connection-in vitro investigation of tightness of internal conical implant-abutment connections against endotoxin penetration. Clin Oral Investig. 2010; 14: 427-32.

9. do Nascimento C, Pedrazzi V, Miani PK, Moreira LD, de Albuquerque RF, Jr. Influence of repeated screw tightening on bacterial leakage along the implant-abutment interface. Clin Oral Implants Res. 2009; 20: 1394-7.

10. do Nascimento C, Miani PK, Pedrazzi V, Gonçalves RB, Ribeiro RF, Faria $A C$, et al. Leakage of saliva through the implant-abutment interface: in vitro evaluation of three different implant connections under unloaded and loaded conditions. Int J Oral Maxillofac Implants. 2012; 27: 551-60.

11. Coelho PG, Sudack P, Suzuki M, Kurtz KS, Romanos GE, Silva NR. In vitro evaluation of the implant abutment connection sealing capability of different implant systems. J Oral Rehabil. 2008; 35: 917-24.

12. Jaworski ME, Melo AC, Picheth CM, Sartori IA. Analysis of the bacterial seal at the implant-abutment interface in external-hexagon and Morse taperconnection implants: an in vitro study using a new methodology. Int J Oral Maxillofac Implants. 2012; 27: 1091-5.

13. Steinebrunner L, Wolfart S, Bossmann K, Kern M. In vitro evaluation of bacterial leakage along the implant-abutment interface of different implant systems. Int J Oral Maxillofac Implants. 2005; 20: 875-81.

14. Silva-Neto JP, Prudente MS, Carneiro T de A, Nobilo MA, Penatti MP, Neves FD. Micro-leakage at the implant-abutment interface with different tightening torques in vitro. J Appl Oral Sci. 2012; 20: 581-7.

15. Silva-Neto JP, Nobilo MA, Penatti MP, Simamoto PC, Jr., Neves FD. Influence of methodologic aspects on the results of implant-abutment interface microleakage tests: a critical review of in vitro studies. Int J Oral Maxillofac Implants. 2012; 27: 793-800.
16. Besimo CE, Guindy JS, Lewetag D, Meyer J. Prevention of bacterial leakage into and from prefabricated screw-retained crowns on implants in vitro. Int J Oral Maxillofac Implants. 1999; 14: 654-60.

17. do Nascimento C, Miani PK, Pedrazzi V, Muller K, de Albuquerque RF Jr. Bacterial leakage along the implant-abutment interface: culture and DNA checkerboard hybridization analyses. Clin Oral Implants Res.. 2012; 23: $1168-72$.

18. Gross M, Abramovich I, Weiss El. Microleakage at the abutment-implant interface of osseointegrated implants: a comparative study. Int J Oral Maxillofac Implants. 1999; 14: 94-100.

19. Broggini N, McManus LM, Hermann JS, Medina R, Schenk RK, Buser D, et al. Peri-implant inflammation defined by the implant-abutment interface. J Dent Res. 2006; 85: 473-8.

20. Bozkaya D, Muftu S. Mechanics of the taper integrated screwed-in (TIS) abutments used in dental implants. J Biomech. 2005; 38: 87-97.

21. Donovan R, Fetner A, Koutouzis T, Lundgren T. Crestal bone changes around implants with reduced abutment diameter placed non-submerged and at subcrestal positions: a 1-year radiographic evaluation. J Periodontol. 2010; 81: 428-34. 